УДК 167+303:339.138

JEL Classification: B41, M31

\title{
НОВА ПАРАДИГМА МАРКЕТИНГУ
}

\section{Приходько Д.О., канд. екон. наук \\ Харківський національний автомобільно-дорожнній університет}

Постановка проблеми. У сучасній літературі зазначається невідворотна тенденція виснаження основних природних ресурсів планети. Це призведе до необхідності вирішення виниклої нової, актуальної, глобальної за своїми масштабами проблеми - проблеми зміни справжніх парадигм, розробки, формулювання нових, майбутніх парадигм всіх областей діяльності.

Аналіз останніх досліджень і публікацій. Аналіз останніх досліджень і публікацій показав, що вже в кінці XX - на початку XXI століття здійснювалися спроби розробки нових парадигм. Вперше необхідність в зміні справжньої парадигми економіки, розробці нової ії парадигми була висловлена ще в 1996 році Бартеневим С.О. [1]. Однак іï автором було зроблено лише приблизне уявлення про характер майбутньої парадигми економіки. При цьому він розпливчасто формулює майбутні завдання: «... знайти методологічну нитку, що дозволяє виявити взаємозв'язок між суперечливими процесами ... загальну спрямованість руху глобальних процесів. Поглянути на світ іншими очима. Проблема поставлена і чекає свого рішення». При цьому причина зміни парадигм економіки пов'язувалася не 3 глобальною проблемою виснаження природних ресурсів планети, а 3 системною, світовою кризою - кризою виробництва, менеджменту, наук і парадигм. Однак причину цієї кризи автор визначити не зміг. У 1999 році спробу розробки нової парадигми менеджменту робив і такий досвідчений фахівець в менеджменті, як Пітер Друкер (19092005), автор талановито написаної книги «Завдання менеджменту в XXI столітті» [2]. Але і він обмежився в ній лише підкресленням того, чим менеджмент не $\epsilon$ : «... менеджмент не $\epsilon$ менеджмент бізнесу ...». I як наслідок, він не зміг сформулювати нову парадигму менеджменту.

Праці Амблера Т. присвячені розробці парадигмам маркетингу. Автор виділяє три парадигми маркетингу: неокласична (мікроекономіка), конфліктна (стратегія) i парадигма відносин (співробітництво) [3]. Однак автор тут зазначив лише формулювання маркетингу, а не минулу, теперішню та майбутню (нову) парадигми маркетингу, тобто тут також не було розроблено парадигм маркетингу.

Проблемами визначення парадигм займався Кун Т. [4], проте він обмежився лише розпливчастим трактуванням поняття «парадигма», однак формулюванням парадигм маркетингу він не займався взагалі.

Котлер Ф. змішував поняття «парадигма» та «концепція» [5], і це призвело до того, що він теж фактично не розробив парадигми маркетингу.

Тому необхідно констатувати, що про парадигми маркетингу, а також й 
економіки і менеджменту до останнього часу в цілому в літературі йшла тільки сама загальна і виключно розлога розмова без їх конкретного формулювання. Причина цього в методологічній некомпетентності, що виявляється в нерозумінні суті, природи самих парадигм, відсутності необхідних умов їх успішної розробки і формулювання.

Вперше успішні розробки парадигм були проведені в ХНАДУ у 20132019 роках. Це сталося завдяки використанню ефективних методик будь-якого дослідження - методик «2С70», ВЄО і особливо - введення в 2015 році нових понять: «Основна теорія» і «Основний закон» [6], [7]. При цьому одночасно формувалася адекватна i ефективна методологія i технологія розробки парадигм, що знайшла своє концентроване втілення у створенні універсальної моделі розробки парадигм (УМРП) [8].

Невирішені складові загальної проблеми. Однак до сих пір не була розроблена парадигма маркетингу, що $\mathrm{i}$ явилося предметом даного дослідження.

Формулювання цілей статті. Метою цього дослідження явилося формулювання нової (майбутньої) парадигми маркетингу. Для iï вирішення були поставлені такі завдання: провести аналіз еволюції поглядів на поняття «парадигма»; сформулювати основний закон маркетингу; обгрунтувати вибір методики апробації основного закону маркетингу; апробувати основний закон маркетингу методикою «час» (методикою історичного-логічного Гегеля); сформулювати минулу, теперішню, майбутню парадигми маркетингу; узагальнити отримані результати.

Для вирішення завдань застосовувалися методики: огляд літературних джерел, історичного-логічного, аналогії, 2C70, ВСО, теорія методу Бабайлова В.К. $[9,10]$.

Викладення основного матеріалу дослідження. Аналіз еволюції поглядів на поняття «парадигма» показав, що термін «парадигма» має давню історію. Як наголошується в літературних джерелах термін «парадигма»

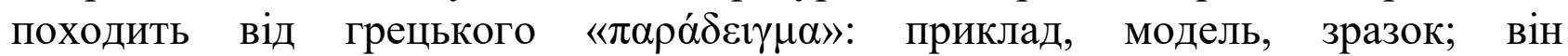
зустрічається вже у Платона [11]. Термін «парадигма» проте не знаходив широкого поширення і загальновизнаного розуміння протягом тисячоліть i застосовувався в основному в специфічних, достатньо вузьких аспектах різних філософських вчень аж до ХХ століття.

Широкого розповсюдження термін «парадигма» набуває після робіт американського історика фізики Томаса Семюеля Куна (1922-1996), який вніс значний вклад в розвиток уявлення про парадигми [4]. Томас Кун, вперше використав в 1962 році словосполучення «зміна парадигм» (англ. «paradigm shift»).

Під парадигмою Кун розумів «... визнані всіма наукові досягнення, які протягом певного часу дають модель постановки проблем і їх рішень ...» [4]. Однак це було надто загальне уявлення парадигм і воно не знайшло свого конкретного втілення в практиці розробки парадигм конкретних сфер діяльності: економіки, менеджменту, підприємництва та інших. 
Але i в більшості справжніх літературних джерел «парадигма» визначається виключно багатослівно.

Прогрес в розумінні природи парадигм стався в 2013-2019 роках. Саме 3 цього моменту стався прорив до розуміння суті парадигми. Вона формулюється вже максимально коротко як глобальна стратегія, як стратегія поведінки всього людства в конкретній сфері діяльності (економіці, менеджменті, підприємництві, в педагогіці вищої школи) [12]. I особливо важливим був висновок, що парадигма є й одним з чотирьох елементів змісту науки поряд 3 їі об’єктом (основною теорією), предметом (основним законом) i методикою апробації (часом). Вперше було доведено, що без парадигми немає і науки. Це не тільки привело до розуміння важливої ролі парадигм і визначенню їхнього справжнього місця в системі знань, а й поглибило розуміння самої науки.

Але особливо важливим було відкриття того, що парадигма - наслідок апробації основного закону будь-якого напрямку діяльності методикою час. Тобто, причина кардинального повороту в розумінні природи парадигм i особливого прогресу в розробці парадигм стався після введення таких двох нових найважливіших понять як «основна теорія» і «основний закон» [7].

Основний закон маркетингу фактично - це його сутність. Під сутністю маркетингу необхідно розуміти організацію будь-яких ринків. Звідси випливає, що предметом основного закону маркетингу є ринки.

Для обгрунтування вибору методики апробації основного закону маркетингу автор використовував методику час. Фактично методика апробації час - це відома методика єдності історичного і логічного, або коротко методика історичного-логічного, розроблена Гегелем [13].

Апробація основного закону маркетингу методикою час i вся теорія i практика маркетингу, а також характер вже розроблених парадигм економіки, менеджменту і підприємництва свідчать, що на всіх історичних відрізках часу присутні три основних типи ринків: ринок продуктів; ринок технологій; ринок методологій. Всі без винятку інші ринки є їх складовими. Але в різні епохи переважним є один 3 трьох. Аналіз ситуації показав, що на самому початку людської цивілізації, під час доіндустріальної епохи переважав ринок продуктів. Він і визначав панування глобальної стратегї організації ринку продуктів, тобто відповідав минулій парадигмі маркетингу. Теперішня парадигма маркетингу, яка характерна для індустріальної епохи - це глобальна стратегія організації ринку технологій. Майбутня парадигма маркетингу, що характерна для постіндустріальної епохи - це глобальна стратегія організації ринку методологій.

Необхідно зауважити, що весь процес розробки парадигм маркетингу фактично відбувався на основі моделі розробки парадигми в формі таблиці 1. 
Модель розробки парадигм маркетингу

\begin{tabular}{|c|c|c|c|}
\hline \multirow{3}{*}{$\begin{array}{l}\text { Фундаментальні } \\
\text { методики }\end{array}$} & \multicolumn{3}{|c|}{ Методики і результати їх застосування } \\
\hline & $\begin{array}{l}\text { Визначення } \\
\text { об’єкта }\end{array}$ & $\begin{array}{l}\text { Визначення предмета } \\
\text { (проблемної частини } \\
\text { об'єкта) }\end{array}$ & Методика вирішення проблеми \\
\hline & Об’єкт & Проблема & Результат вирішення проблеми \\
\hline \multirow[b]{2}{*}{ Ідея } & \multirow[b]{2}{*}{ Методологія } & \multirow[b]{2}{*}{$\begin{array}{l}\text { Невідомість зв’язку } \\
\text { маркетингу з ринками }\end{array}$} & Інтуїція \\
\hline & & & $\begin{array}{lcc}\text { Залежність } & \text { (якісний } & \text { зв’язок } \\
\text { маркетингу } & 3 & \text { організацією } \\
\text { наприклад, } & 3 & \text { ринком прів, прддуктів). } \\
\text { «Маркетинг } & \text { пов’язаний } \\
\text { організацією ринку продуктів» }\end{array}$ \\
\hline \multirow[b]{2}{*}{ Гіпотеза } & \multirow[b]{2}{*}{ Ідея } & \multirow{2}{*}{$\begin{array}{l}\text { Невідомість } \\
\text { кількісного } \quad \text { зв'язку } \\
\text { маркетингу та ринку }\end{array}$} & Логіка дискретних фактів \\
\hline & & & $\begin{array}{l}\text { Закономірність (дискретний якісний і } \\
\text { кількісний зв'язок) }\end{array}$ \\
\hline \multirow[b]{2}{*}{ Концепція } & \multirow[b]{2}{*}{ Гіпотеза } & \multirow{2}{*}{$\begin{array}{l}\text { Невідомість } \\
\text { суцільного } \\
\text { кількісного } \quad \text { зв'язку } \\
\text { маркетингу та ринку }\end{array}$} & Логіка доказу, розрахунку \\
\hline & & & $\begin{array}{l}\text { Закон (доведений, розрахований } \\
\text { суцільний зв’язок): «Маркетинг - це } \\
\text { організація ринку продуктів» }\end{array}$ \\
\hline \multirow[b]{2}{*}{ Теорія } & \multirow[b]{2}{*}{ Концепція } & \multirow{2}{*}{$\begin{array}{l}\text { Закон, що не } \\
\text { апробований іншими } \\
\text { законами маркетингу }\end{array}$} & Взаємоапробація \\
\hline & & & $\begin{array}{l}\text { Закон (апробований } \\
\text { законами маркетингу). } \\
\end{array}$ \\
\hline \multirow{2}{*}{ Основна теорія } & \multirow{2}{*}{ Теорії окремі } & \multirow{2}{*}{$\begin{array}{l}\text { Відсутність } \\
\text { узагальнення окремих } \\
\text { законів маркетингу }\end{array}$} & \begin{tabular}{|lll} 
Узагальнення & окремих \\
методології & законів \\
\end{tabular} \\
\hline & & & $\begin{array}{l}\text { Основний закон: «Маркетинг - це } \\
\text { організація будь-яких ринків» }\end{array}$ \\
\hline \multirow[b]{2}{*}{ Наука } & \multirow[b]{2}{*}{$\begin{array}{l}\text { Основна } \\
\text { теорія }\end{array}$} & \multirow[b]{2}{*}{$\begin{array}{l}\text { Основний закон } \\
\text { маркетингу, що не } \\
\text { апробований Часом }\end{array}$} & Час \\
\hline & & & $\begin{array}{l}\text { Три основні закони маркетингу в } \\
\text { залежності від часу (історичних } \\
\text { епох), тобто три парадигми } \\
\text { маркетингу (три глобальні стратегії } \\
\text { маркетингу) }\end{array}$ \\
\hline
\end{tabular}

Джерело: розроблено автором за [8, 14]

3 таблиці слідує, що парадигми маркетингу - це результати конкретизації його основного закону. Це дає підставу трактувати будь-яку парадигму ще й як конкретний, або окремий закон. Такий окремий закон особливий: виводиться 3 основного, але не раніше його; сам змінюється в часі, причому поступово (тільки зі зміною епох) і тільки за формою - через зміну форми переважаючого ринку (внутрішній його зміст залишається незмінним - маркетинг завжди $\epsilon$ організацією ринку).

Висновки 3 проведеного дослідження. Під час вирішення останнього завдання даного дослідження (узагальнити отримані результати) були отримані такі результати: проведено аналіз еволюції поглядів на поняття «парадигма»; сформульовано основний закон маркетингу; обгрунтовано вибір методики апробації основного закону маркетингу; апробовано основний закон маркетингу методикою час; сформульовані три парадигми маркетингу (минула 
парадигма маркетингу - це глобальна стратегія організації ринку продуктів; теперішня парадигма маркетингу - це глобальна стратегія організації ринку технік; нова (майбутня) парадигма маркетингу - це глобальна стратегія організації ринку методологій).

Проведене дослідження сприяло подальшому поглибленню розуміння самих парадигм.

Отримані результати дозволяють визначити перспективи майбутніх досліджень: розробку парадигм психології, соціології, адміністративної сфери діяльності.

\section{Перелік посилань}

1. Бартенев С. А. Экономические теории и школы (история и современность): курс лекций. Москва: БЕК, 1996. 352 с.

2. Новая парадигма менеджмента (Питер Друкер). HR-Портал : сайт. URL: http://hr-portal.ru/article/novaya-paradigma-menedzhmenta (дата обращения: 27.03.2019).

3. Амблер Т. Практический маркетинг (Серия «Теория и практика менеджмента») / пер. с англ. под ред. Ю. Н. Каптуревского. Санкт-Петербург : Питер, 1999. 400 c.

4. Кун Томас Сэмюэл. Википедия : сайт. URL: https://is.gd/g4Iibm (дата обращения: 27.03.2019).

5. Парадигмы маркетинга. Marketopedia : сайт. URL: http://marketopedia.ru/7-paradigmy-marketinga.html дата обращения: 27.03.2018).

6. Бабайлов В. К. Новая парадигма экономики. Новий колегіум. 2015. № 1. C. $53-57$.

7. Бабайлов В. К. Организация модели разработки парадигм экономики. Проблеми і перспективи розвитку підприємництва: Збірник наукових праиь Харківського начіонального автомобільно-дорожнього університету. Харків : ХНАДУ, 2015. №3 (10), том 2. С. 5 - 9.

8. Бабайлов В. К. Модель разработки парадигм: важнейшие свойства. Новий колегіум. 2016. № 3. С. 48 - 53.

9. Бабайлов В. К. Теория метода : монография. Харків: ХНАДУ, 2011. $232 \mathrm{c}$.

10. Бабайлов В. К. Менеджмент: наука и практика: учебник. Харків : ХНАДУ, 2015. $276 \mathrm{c.}$

11. Светлов Р. В. Парадигма. Платонический философский lexicon. Академия. Материаль и исследования по истории платонизма. СанктПетербург: СПбГУ, 2000. Вып. 2. С. 345 - 346.

12. Бабайлов В. К. Новая парадигма менеджмента. Проблеми $i$ перспективи розвитку підприємнищтва: Збірник наукових праџь Харківського національного автомобільно-дорожнього університету. Харків : ХНАДУ, 2016. №3 (14), том 1. С. $72-76$.

13. Принцип единства исторического и логического. Википедия : сайт. URL: https://is.gd/hBuY4N (дата обращения: 30.03.2019).

14. Бабайлов В. К. Анализ и синтез. Бизнес-Информ. 2012. № 4. С. 16 - 17. 


\section{References}

1. Bartenev, S. (1996), Economic theories and schools (history and modern times): course of lectures [Ekonomicheskie teorii i shkoly (istoriya i sovremennost'): kurs lektsiy], Moscow: BEK, $352 \mathrm{p}$.

2. «New management paradigm (Peter Drucker). HR-Portal» [«Novaya paradigma menedzhmenta (Piter Druker). HR-Portal»], available at : http://hrportal.ru/article/novaya-paradigma-menedzhmenta (last accessed 27.03.2019).

3. Ambler, T. (1999), Practical marketing (Series «Theory and Practice of Management»). Trans. from Eng. edited by Kapturevsky Yu. N. [Prakticheskiy marketing (Seriya «Teoriya $i$ praktika menedzhmenta»). Perevedeno s ang. pod redaktsiey Kapturevskogo Yu. N.], St. Petersburg: Peter, 400 p.

4. «Kuhn Thomas Samuel. Wikipedia» [«Kun Tomas Semyuel. Vikipediya»], available at : https://is.gd/g4Iibm (last accessed 27.03.2019).

5. «Marketing paradigms. Marketopedia» [«Paradigmy marketinga. Marketopedia»], available at : http://marketopedia.ru/7-paradigmy-marketinga.html (last accessed 27.03.2019).

6. Babailov, V. (2015), «New paradigm of economy» [«Novaya paradigma ekonomiki»], Novyi kolehium, No. 1, P. 53 - 57.

7. Babaylov, V. (2015), «Organization of a model for the development of economic paradigms» [«Organizatsiya modeli razrabotki paradigm ekonomiki»], Problems and prospects of entrepreneurship development: Collection of scientific works of the Kharkiv National Automobile and Road University, No. 3 (10), Vol. 2, P. 5-9.

8. Babailov, V. (2016), «Model development paradigms: the most important properties» [«Model' razrabotki paradigm: vazhneyshie svoystva»], New Collegium, No. 3, P. 48-53.

9. Babailov, V. (2011), Theory of method: monograph [Teoriya metoda: monografiya], Kharkiv: KhNADU, 232 p.

10. Babailov, V. (2015), Management: science and practice: textbook [Menedzhment: nauka i praktika: uchebnik], Kharkiv: KhNADU, 276 p.

11. Svetlov, R. (2000), «Paradigm. Platonic Philosophical lexicon» [«Paradigma. Platonicheskiy filosofskiy lexicon»], Akademiya. Materialy $i$ issledovaniya po istorii platonizma, No. 2, P. 345-346.

12. Babailov, V. (2016), «New paradigm of management» [«Novaya paradigma menedzhmenta»], Problems and prospects of entrepreneurship development: Collection of scientific works of the Kharkiv National Automobile and Road University, No. 3 (14), Vol. 1, P. 72-76.

13. «The principle of unity of historical and logical. Wikipedia, the free encyclopedia» [«Printsip edinstva istoricheskogo i logicheskogo. Material iz Vikipedii - svobodnoy entsiklopedii»], available at : https://is.gd/hBuY4N (last accessed 28.03.2019).

14. Babailov, V. (2012), «Analysis and synthesis» [«Analiz i sintez»], BiznesInform, No. 4, P. 16-17. 


\section{РЕФЕРАТИ РЕФЕРАТЫ ABSTRACTS}

\section{УДК 167+303:339.138; JEL Classification: B41, М31}

\section{ПрихоДЬКО Д.О. НОВА ПАРАДИГМА МАРКЕТИНГУ}

У сучасній літературі зазначається невідворотна тенденція виснаження основних природних ресурсів планети. Це призведе до необхідності вирішення виниклої нової, актуальної, глобальної за своїми масштабами проблеми проблеми зміни справжніх парадигм, розробки, формулювання нових, майбутніх парадигм всіх областей діяльності. Метою цього дослідження явилося формулювання нової (майбутньої) парадигми маркетингу. Методики дослідження. Для досягнення поставленої мети та вирішення завдань в роботі застосовувалися методики: огляд літературних джерел, історичного-логічного, аналогії, 2С70, ВСО, теорія методу Бабайлова В.К. Результати дослідження: проведено аналіз еволюції поглядів на поняття «парадигма»; сформульовано основний закон маркетингу; обгрунтовано вибір методики апробації основного закону маркетингу; апробовано основний закон маркетингу методикою час; сформульовані три парадигми маркетингу (минула парадигма маркетингу - це глобальна стратегія організації ринку продуктів; теперішня парадигма маркетингу - це глобальна стратегія організації ринку технік; нова (майбутня) парадигма маркетингу - це глобальна стратегія організації ринку методологій). Наукова новизна: обгрунтування характеру минулої, теперішньої та нової (майбутньої) парадигм маркетингу як глобальних стратегій в сфері організації інновацій. Практична значущість. Впровадження теперішньої і нової (майбутньої) парадигм маркетингу в стратегічне планування підприємства призведе до вдосконалення його методології, а це, в свою чергу, підвищить ефективність всього менеджменту і виробництва. Проведене дослідження сприяло подальшому поглибленню розуміння самих парадигм. Отримані результати дозволяють визначити перспективи майбутніх досліджень: розробку парадигм психології, соціології, адміністративної сфери діяльності.

Ключові слова: маркетинг; продукт; технологія; методологія; модель; парадигма.

\section{УДК 167+303:339.138; JEL Classification: B41, М31}

\section{ПриходЬКо Д.А. НОВАЯ ПАРАДИГМА МАРКЕТИНГА}

В современной литературе отмечается неотватимая тенденция истощения основных природных ресурсов планеты. Это приведет к необходимости решения возникшей новой, актуальной, глобальной по своим масштабам проблемы - проблемы смены настоящих парадигм, разработки, формулирования новых, будущих парадигм всех областей деятельности. Целью настоящего исследования явилось формулирование новой (будущей) парадигмы маркетинга. Методики исследования. Для достижения поставленной цели и решения задач в работе применялись методики: обзор литературных источников, исторического-логического, аналогии, 2С70, ВЕО, теория метода Бабайлова В.К. Результаты исследования: проведен анализ 
эволюции взглядов на понятие «парадигма»; сформулирован основной закон маркетинга; обоснован выбор методики апробации основного закона маркетинга; апробирован основной закон маркетинга методикой время; сформулированы три парадигмы маркетинга (прошла парадигма маркетинга это глобальная стратегия организации рынка продуктов; настоящая парадигма маркетинга - это глобальная стратегия организации рынка техник; новая (будущая) парадигма маркетинга - это глобальная стратегия организации рынка методологий). Научная новизна: обоснование характера прошлой, настоящей и новой (будущей) парадигм маркетинга как глобальных стратегий в сфере организации инноваций. Практическая значимость. Внедрение настоящей и новой (будущей) парадигм маркетинга в стратегическое планирование предприятия приведет к совершенствованию его методологии, а это, в свою очередь, повысит эффективность всего менеджмента и производства. Проведенное исследование способствовало дальнейшему углублению понимания самих парадигм. Полученные результаты позволяют определить перспективы будущих исследований: разработку парадигм психологии, социологии, административной сферы деятельности.

Ключевые слова: маркетинг; продукт; технология; методология; модель; парадигма.

\section{UDC 167+303:339.138; JEL Classification: B41, M31 \\ Prykhodko D. NEW PARADIGM OF MARKETING}

An inevitable tendency of depletion of the main natural resources of the planet registers in modern literature. This will lead to the need to address the emerging new, relevant, global in scale problem - the problem of changing present paradigms, developing, formulating new, future paradigms of all scopes of activity. Purpose: to formulation of a new (future) paradigm of marketing. Methodology of research: review of literary sources, historical-logical, analogy, 2C70, BEO, theory of the method Babaylov's V.K. Findings: The evolution of views on the concept of «paradigm» has been analysed. The basic law of marketing has been formulated. The choice of methodology of testing the basic law of marketing has been justified. The basic law of marketing by time methodology has been tested. Three paradigms of marketing (the past paradigm of marketing is the global strategy for organizing the market of products; the present paradigm of marketing is the global strategy for organizing the market of technologies; the new (future) paradigm of marketing is the global strategy for organizing the market of methodologies) have been formulated. Originality: the nature of past, present and new (future) paradigms of marketing as global strategies in the sphere of innovation has been substantiated. Practical value: The introduction of the present and the new (future) paradigms of marketing in the strategic planning of the enterprise will lead to the improvement of its methodology, and this, in turn, will increase the efficiency of the entire management and production. The research that has been conducted, to promoted further deepening the understanding of the paradigms themselves. The results that has been obtained, allow 
to determine the prospects for future research: the development of paradigms of psychology, sociology, and the administrative sphere of activity.

Key words: marketing; product; technology; methodology; model; paradigm.

\section{Відомості про авторів / Сведения об авторах / About the Authors}

Приходько Дар'я Олександрівна - кандидат економічних наук, Харківський національний автомобільно-дорожній університет, доцент кафедри економіки і підприємництва, м. Харків, Україна; e-mail: zajada@gmail.com; ORCID ID: https://orcid.org/0000-0003-3925-4828. Моб. 066-97-44-135.

Приходько Дарья Александровна - кандидат экономических наук, Харьковский национальный автомобильно-дорожный университет, доцент кафедры экономики и предпринимательства, г. Харьков, Украина.

Prykhodko Daria - Candidate of Sciences (Economics), Kharkiv National Automobile and Highway University, Associate Professor of the Department of Economics and Entrepreneurship, Kharkiv, Ukraine. 